\title{
Borsa İstanbul'da İşlem Gören Otomotiv İmalat Sektörü Firmalarının Finansal Performanslarının AHP, TOPSIS, ELECTRE ve VIKOR Yöntemleri ile Analizi
}

Lokman YANIK ${ }^{1}$

Tamer EREN ${ }^{2}$

Özet

Firmaların finansal performanslarının analizi yatırım ve işletmelerle rekabet edebilme açısından çok önem arz etmektedir. Özellikle otomotiv gibi imalat sanayisinde çok önemli bir yeri olan sektör için finansal performans analizi mutlaka incelenmesi gereken bir konudur. Bu hususta doğru kararı vererek getiri elde etmek amacıyla en uygun yatırımı seçmek önemli bir karar problemidir. Bu amaçla çalışmada, üç ayrı uygulama yapılmıştır. Uygulamada BIST-100 de işlem gören otomotiv imalat sektöründeki 11 ayrı firma incelenmiştir. İşletmelerdeki karar vericilerin, ellerinde bulunan birçok finansal verinin düzenlenip tek bir skor hâlinde sunulmasında, çok kriterli karar verme yöntemlerinden TOPSIS, VIKOR, ELECTRE yöntemleri kullanılmıştır. Karar vermede kullanılacak kriterlerin birbirlerine göre ağırlıkları bütün yöntemlerde AHP yöntemi kullanılarak elde edilmiştir. Elde edilen skorların 2011-2015 yıllarına ait finansal performansları ve performans siralaması bulunmuştur.

Anahtar Kelimler: Çok Ölçütlü Karar Verme Yöntemleri, Finansal Performans, AHP, TOPSIS, ELECTRE, VIKOR

\section{Analysis of Financial Performances of Automotive Manufacturing Sector Companies Which is Tradedin Istanbul Stock Exchange by AHP, TOPSIS, ELECTRE and VIKOR Methods}

\begin{abstract}
Analysis of the financial performance of the companies is very important for investment and ability to compete for businesses. For the sector that has a very important place especially in manufacturing industries such as automotive, the financial performance analysis is an issue that surely must be examined. In order to obtain a return by giving the right decision on this issue, selecting the most appropriate investment is an important decision problem. For this purpose, three separate implementations were done in study. In practice, 11 different companies which istraded in BIST-100 in automotive manufacturing sector were examined. In arranging and presenting in a single score of many financial data in the hands of decision in businesses, TOPSIS, VIKOR, and ELECTRE methods of multicriteria decision-makingmethods were used. Weights relative to each other of the criteria to be used in decision making were obtained by using AHP method in all methods. Financial performance for the years 2011-2015 of the obtained scores and performance ranking were found.
\end{abstract}

Key words: Multi Criteria Decision Making, Financial Performance, AHP, TOPSIS, ELECTRE, VIKOR

\section{Giriş}

Globalleşen Dünya'da otomotiv sektörü hızla gelişen ve ülkelerin ekonomileri için gittikçe önemi artan bir sektördür. Türkiye'de otomotiv sektörünün imalat sanayi

\footnotetext{
${ }^{1}$ Lisans Öğrencisi, Kırıkkale Üniversitesi, Endüstri Mühendisliği Bölümü, yaniklokman@ gmail.com

2 Doç. Dr., Kırıkkale Üniversitesi., Endüstri Mühendisliği Bölümü, tamereren@gmail.com
} 
toplam üretimi içindeki payı imalat sanayi sektörler ortalamasının üzerindedir. Karar verme problemlerinin temelinde bulunan soruların yanitlarını veren işletmelerin yönetim faaliyetlerinde yönetimin odak noktası, verilen kararların yerine getirilmesinde ve eyleme dökülmesindeki etkinlik derecesi olmalıdır. Birden fazla seçeneğin arasından birisi seçme işi karar verme problemi olarak tanımlanmaktadır. Bu seçimi yaparken ele alınan problem için detaylı ve yeterli bilginin toplanması ve çözüm süreci için analizlerin yapılması gerekmektedir. $\mathrm{Bu}$ analizlere göre içlerinden en uygun olanını seçmek problemi çözme faaliyetidir. Günümüzdeki ekonomik şartlarında işletmelerin değerlendirilmesinde yalnızca mali tablolardan elde edilen oranların kullanılması yeterli olmamaktadır. Bu açıdan son yıllarda kullanılan çok ölçütlü karar verme yöntemleriyle, birbirleriyle çelişebilen kriterlerin basit düzeyde karar almaya yardımcı olmalarıyla çok kapsamlı bir alana sahip olmuşlardır. Finans literatüründe de çok sayıdaki analiz sonuçlarını bir tek skora indirmek için çalışmalar mevcuttur. Çok ölçütlü karar verme yöntemleri AHP, TOPSIS, VIKOR, ELECTRE, PROMETHEE vb. geliştirilen yöntemlerden bazılarıdır.

$\mathrm{Bu}$ uygulamada otomotiv sektöründeki firmaların finansal performansları 20112015 yıllarındaki mali tablolarından elde edilen veriler 1şığında, belirli kriterler dâhilinde AHP, TOPSIS, VIKOR ve ELECTRE yöntemleri ile analiz edilmiştir. Firmaların 2011-2015 yılları arasındaki getiri oranlarına göre en iyiden en kötüye doğru sıralamaları bulunmuş ve sonuç kısmında değerlendirilmiştir.

Yapılan çalışmanın planı şu şekildedir: Çalışmanın birinci bölümünde finansal performanstan ve öneminden bahsedilmiştir. İkinci bölümünde otomotiv sektörüne değinilmiştir. Üçüncü bölümünde çok kriterli karar verme tekniklerinden bahsedilmiş, bunlardan AHP, TOPSIS, ELECTRE ve VIKOR yöntemlerine ait bilgiler verilmiştir. Dördüncü bölümde literatürde yapılan çalışmalar incelenmiştir. Beşinci bölümde uygulamaya geçilmiştir. Daha sonra sonuç ve değerlendirme yapılmıştır. Son kısımda ise kaynakçaya yer verilmiştir.

\section{Finansal Performans Kavramı ve Önemi}

Bir iş veya görev verildiğinde o anda ve sonunda göstermiş olduğu başarı derecesi gibi tanımlamaları olan performans kavramı; temelde, bireylerin veya örgütlerin verilen işte elde edilen sonucun gerçekleşmesini istedikleri hedefle ne kadar örtüştügünün hem nicel hem de nitel göstergesidir (Büyük Larousse, 1992; Karakaş ve Ak, 2003).

Günümüzde yönetim anlayışına göre performans kavramı değişmiştir. Yöneticiler işletmenin başarısını yani amaçlarına ulaşımdaki yeterliliği performans kavramı olarak belirtmektedirler. İşletmenin ve bireyin birlikte gerçekleştirmiş oldukları başarı ve uyum olarak gösterilen bu kavramın önemi, özellikle niceliksel getiriler ile ölçüldüğü zaman giderek artmaktadır (Biçer, 1997; Mistepe, 1998).

İşletme alanı için bu kavram sorgulandığı zaman aynı çerçevede tanımların yapıldığı görülmektedir. İşletmelerin elde ettikleri çıktılar daha çok finansal olarak 
Yalova Sosyal Bilimler Dergisi

ön plana çıkartıldığında bu sonuçların aynı zamanda işletme amacının ve görevlerinin yerine ne ölçüde getirildiğinin derecesini de ölçmektedir (Akal, 2000). İşletmenin nicel ve nitel çıktıları arasındaki ilişkilerin ölçülmesi, bu sonuçların birlikte değerlendirilmesi gerekmektedir. Üretim veya hizmet olarak ele alındığında hitap ettikleri alanların farklılığına bakılmaksızın işletme yararlarını gözetmek hem bireylerin hem de yönetici örgütlerinin esas görevidir (Benligiray, 1999). Temel amaç ve misyon stratejik planlamalarda çok önemlidir. Bununla birlikte bu stratejik planlamalar performans olarak değerlendirilen başarı çıktısı ile aynı çizgiye sahip olmalıdır. Yani içinde bulundukları örgüte katkıda bulunabilecek yeterlilikte ve etkinlikte olmak zorundadır (Grady, 1991).

Günümüzde yaşanan teknolojik gelişmeler ve sosyal faaliyetler performansı arttırmaya yönelik yapılan değişimleri önemli ölçüde etkilemektedir. Ekonomik koşulların beraberinde getirdiği gereklilikler işletmelere bu gelişmeleri takip etme zorunluluğu oluşturmuştur. İşletmelerin bu takibi yapabilmeleri için ekstra duyarlılık gösteren bir organizasyon yapısı oluşturmaları ve kapasitelerini gerektiği durumlarda geliştirmeleri ve performanslarını bu gelişmelerde eş ölçüde tutmaları gerekmektedir (Zerenler, 2003).

\section{Türkiye'deki Otomotiv Sektörü ve Ekonomideki Payı}

Yaşanan teknolojik gelişmelerde Dünya'da ön plana çıkan otomotiv sektörü ekonomik anlamda büyük ölçüde önem kazanmıştır. Sektördeki firmalar arasında artan rekabetin etkisi aynı zamanda gösterilen performanslarda da dikkat çekmektedir. Artan performans değerleri beraberinde verimlilik artışını, kaynakların etkin kullanıldığını, organizasyonlardaki yönetim gücünü ve yetkinliğini ön plana çıkarmıştır. Bu kapsamda rekabette önem arz eden stratejik adımlar yapılan AR-GE destekleri, işgücü istihdamı gibi niceliksel ve niteliksel yatırımlar ile eş değerdir.

Üretimdeki payı değerlendirildiğinde önde gelen sektörlerden olan otomotiv sektörü ise oluşturduğu katma değerler ile ekonomide çok önemli bir yere sahiptir. Otomotiv sektörü farklı sektörler ile iç içe olduğu için ülkenin ekonomisine katkıda bulunmaktadır. Otomotiv sektörünün diğer sektörler üzerinde de etkilerinin olması teknolojik gelişmelerle paralel gitmesine olanak sağlamaktadır. $\mathrm{Bu}$ nedenle sektörde yaşanan değişimler yakından takip edilmelidir. Her sektörün olduğu gibi otomotiv sektörünün de zayıf ve güçlü yanları bulunmaktadır. Kapasite kullanımından kaynaklanan verimsizlikler, artan üretim maliyetleri veya ana ve yan sanayi arasındaki iletişim yetersizliğinden kaynaklanan sinerji eksikliği sektörün zayıf yanlarını oluşturmaktadır. Esnek imalat kabiliyeti, dünya standartlarında oluşturulan ve sürekli geliştirilen kalite sistemi ve güçlü sermaye yapısı gibi özelliklerde sektörün güçlü yanlarını göstermektedir.

Ar-Ge ve üretim birimlerine yapılan 85 Milyar Euro'luk yatırımlar ve bu yatırımları yapan ülkelerin 433 Milyar Euro üzerindeki vergi gelirleri otomotiv sektörünün dünya genelinde en fazla yatırımların yapıldığ 1 sektörlerden biri olduğunu göstermektedir. Ekonomik payı bu kadar güçlü olan sektörün istihdama yaptığı katkı da çok fazladır. Yapılan araştırmalara göre otomotiv sektörü dolaylı 
olarak 50 milyondan daha fazla kişiye hitap ederken doğrudan 8 milyondan fazla istihdama sahip olduğu görülmüştür.

Türkiye'deki otomotiv sektörünün payı incelendiğinde ise 1960'l1 y1llardan bu yana önemli gelişmeler kat etmiştir. İhracat alanında atılan yeni adımlar ile Türkiye'de önemli bir konum haline gelmiştir. 2016 yılı TÜIK verileri incelendiğinde otomotiv sektörü ülkedeki toplam ihracatın \%15'ine hitap etmektedir. Aynı zamanda Türkiye'den toplamda 140 ülkeye 1,1 milyar dolar, AB üyeliği olan 27 ülkeye ise 4,4 milyar dolar ihracat yaptığı kayıt altına alınmıştır.

Uluslararası Motorlu Taşıt Üreticileri Derneği (OICA)'nin yaptığı istatistiklere göre 2014 yılındaki küresel çapta otomotiv üretimi 2015 y1lında \%1 artmış ve bu rakam 90 milyon 683 bin 72'ye ulaşmışır. Ayrıca otomotiv sanayinde toplam üretim şubat ayındaki yine önceki yıla göre $\% 11$ artış göstermiştir.

2016 yılı şubat ayı "Motorlu kara taşıtları, traktörler, bisikletler, motosikletler ve diğer kara taşıtları" ithalatı geçen yılın aynı ayına göre \%8,7 artarak 1 milyar 352 milyon dolar, ihracat1 \%17,4 artarak 1 milyar 651 milyon dolar olmuştur ve yaklaşık 300 milyon dolar dış ticaret fazlası vermiştir. 2016 Ocak-Şubat dönemi "Motorlu kara taşıtları, traktörler, bisikletler, motosikletler ve diğer kara taşıtları" ithalatı geçen yılın aynı dönemine göre \%0,7 azalarak 2 milyar 42 milyon dolar olurken, ihracatı \%1,6 artarak 2 milyar 885 milyon dolar oldu ve yaklaşık 843 milyon dolar dış ticaret fazlası vermiştir.

\section{3. Çok Ölçütlü Karar Verme Yöntemleri}

Chen ve Hwan (1992) tarafindan Hwang ve Yoon'un (1981)'un çalışmalarından temel alınarak geliştirilen TOPSIS yöntemi çok ölçütlü karar verme yöntemleri arasında gösterilmektedir. Karar verme problemlerinde yaşanan karmaşılara çözüm getirebilme amaçlı geliştirilen bu yöntemde, alternatif seçenek kümesi arasında belirli faktörler değerlendirilerek etkili olan kriterlerin alacağ 1 maksimum ve minimum değerlerin ideal durumla karşılaştırılması olarak tanımlanmaktadır (Yurdakul ve İç, 2003). " $n$ " sayıda alternatif ve " $m$ " sayıda kriteri bulunan problem teoride "m" boyutlu uzayda " $n$ " noktaları ile gösterilmektedir. Alternatifler çözüm süreçlerindeki aldıkları değerler ile ideal çözüm noktasına olan mesafelerinin değerlendirmesini yapan TOPSIS yöntemi en uygun alternatifin seçimine yönelik mantıkla çalışmaktadır (Eleren ve Karagül, 2008).

1980'de Saaty tarafindan geliştirilen Analitik Hiyerarşi Prosesi (AHP) yöntemi ise yine karmaşık karar verme problemlerin çözümüne yardımcı olarak kullanılan çok ölçütlü karar verme yöntemlerinden birisidir. Çeşitli alanlarda uygulanma imkânı bulan bu yöntem özellikle ekonomi, planlama, portföy yönetimi gibi alanlarda baş göstermektedir. Çok ölçütlü karar verme yöntemlerinden bir diğer yöntem olan VIKOR yöntemi ise karmaşık ve kompleks sitemler için geliştirilmiştir (TzengandHuang, 2011). Yu (1973) ve Zeleny (1982) tarafindan ilk olarak temelleri atılan uzlaşık çözüm, çelişkili kriterler arasında karar vermeye yardımcı uzlaşık çözüm aracı olarak karşımıza çıkmaktadır. Bu yöntem ideale en yakın alternatif çözümü karar vericilere sunmaktadır. Trajkovic vd. (1997), tarafından temellendirilen bu yöntem seçenek kümesinde bulunan birden fazla alternatifi 
Yalova Sosyal Bilimler Dergisi

sırlama ve seçme üzerinde çalışırken nihai kararda uzlaşmacı çözümleri belirler (Demirel ve Yücenur, 2011).

ELECTRE yöntemi ilk olarak Beneyoun(1966) tarafından ortaya atılmış çok ölçütlü karar verme yöntemidir. Yöntem, her bir kriter için alternatifler arasında ikili üstünlük karşılaştırmasına dayanır. Ayrıca bu yöntem öne geçme veya baskınlık ilişkisine dayanan bir yöntemdir, her bir kriter için bir verimlilik bir de önem ölçüsü tespit edilir. Belirlenen verimlilik kriterleri üzerinden her bir seçeneğe puan verilir.

\subsection{AHP Yöntemi}

Aşağıda AHP yönteminin adımları verilmiştir.

Adım 1: Karar verilecek problemin anlaşılabilir ve değerlendirilebilir olması için hiyerarşik olarak düzenlemek gerekir. Bunun için karar probleminin ana hedefi, kriterler, alt kriterler ve alternatifleri hiyerarşik bir yapıda hazırlanır. Karar vericilerin değerlendirmelerine göre kriterlerin birbirleriyle karşılaştırılmasıdır. Karşılaştırmalar yapılırken daha çok tercih ölçeği kullanılmaktadır(Saaty,1980).

Adım 2: Normalizasyon kullanılarak ikili karşılaştırma matrisinin her elemanının göreli önemi hesaplanmaktadır.

Adım 3: Bu aşamada $A \times w=\lambda_{\max } \times w$ eşitliğini sağlayan $\lambda_{\max }$ özvektörü elde edilmelidir. A karşılaştırma matrisini ifade ederken $\mathrm{w}$ ise elde edilen ağırlık matrisini ifade etmektedir. (3.1) ve (3.2)'deki formüller aracıllğılyla tutarlılık oranı (CR) bulunur. CI, tutarlılık indeksini ve RI' da rassallık göstergesini ifade etmektedir. Rassallık göstergesi matrisin boyutuna göre farklı değerler alan sabit değerlerden oluşmaktadır.CR $<0,1$ olması uygulamanın tutarlı olduğunu gösterir.

$$
\begin{aligned}
& C I=\frac{\lambda \max -n}{n-1} \\
& C R=\frac{C I}{R I}
\end{aligned}
$$

Adım 4: Bu adımda, her bir kriterin hesaplanan ağırlığı ile alternatifin o kritere göreağırlıklarınn çarpımları toplamı ilgili alternatifin öncelik değerini verecektir.

\subsection{TOPSIS Yöntemi}

Aşağıda TOPSIS yönteminin adımları tanımlanmıştır.

Adım 1: Karar Matrisinin (A) Oluşturulması

Başlangıç matrisi olarak adlandırılan karar matrisinin satırlarında üstünlükleri sıralanmak istenen karar noktaları yer alırken sütunlarında ise karar vermede kullanılacak değerlendirme faktörleri bulunmaktadır. Karar matrisi aşağıdaki gibi gösterilir: 
Yalova Sosyal Bilimler Dergisi

$A_{i j}$ Matrisinde m karar noktası sayısını, n değerlendirme faktörü sayısını verir.

Adım 2: Standart Karar Matrisinin (R) Oluşturulması

Standart Karar Matrisi, A matrisinin elemanlarından yararlanarak ve aşağıdaki formül kullanılarak hesaplanır.

$$
r_{i j}=\frac{a_{i j}}{\sqrt{\sum_{k=1}^{m} a_{k j}^{2}}}
$$

Adım 3: Ağırlıklı Standart Karar Matrisinin (V) Oluşturulması

Öncelikle değerlendirme kriterlerine ilişkin ağırlıklar $w_{i}$ belirlenir. Daha sonra matrisinin her bir sütunundaki elemanlar ilgili ağırlık değeri ile çarpılarak V matrisi oluşturulur.

Adım 4: İdeal $\left(A^{*}\right)$ ve Negatif İdeal $\left(A^{-}\right)$Çözümlerin Oluşturulması

İdeal çözüm setinin oluşturulabilmesi için V matrisindeki sütun değerlerinin en büyükleri seçilir. İdeal çözüm setinin bulunması aşağıdaki formülde gösterilmiştir.

$$
A^{*}=\left\{\left(\max _{i} v_{i j} \mid j \in J\right),\left(\min _{i} v_{i j} \mid j \in J^{\prime}\right\}\right.
$$

(3.4) formülünden hesaplanacak set $A^{*}=\left\{v_{1}^{*}, v_{2}^{*}, \ldots, v_{n}^{*}\right\}$ şeklinde gösterilebilir. Negatif ideal çözüm seti ise, $V$ sütun değerlerinin en küçükleri seçilerek oluşturulur. Negatif ideal çözüm setinin bulunması aşağıdaki formülde gösterilmiştir.

$A^{-}=\left\{\left(\min _{i} v_{i j} \mid j \in J\right),\left(\max _{i} v_{i j} \mid j \in J^{\prime}\right\}\right.$

(3.5) formülünden hesaplanacak set $A^{-}=\left\{v_{1}^{-}, v_{2}^{-}, \ldots, v_{n}^{-}\right\}$şeklinde gösterilebilir. Formüllerde yer alan $\boldsymbol{J}$ fayda (maksimizasyon), $\boldsymbol{J}^{\prime}$ ise kayip (minimizasyon) değerini göstermektedir.

Adım 5: Ayırım Ölçülerinin Hesaplanması

TOPSIS yönteminde her bir karar noktasına ilişkin değerlendirme faktör değerinin ideal ve negatif ideal çözüm setinden sapmaları bulunmaktadır. İdeal ayırım $\left(\mathrm{S}_{\mathrm{i}}{ }^{*}\right)$ ölçüsünün hesaplanması (3.6) formülünde, negatif ideal ayırım $\left(\mathrm{S}_{\mathrm{i}}^{-}\right)$ölçüsünün hesaplanması ise (3.7) formülünde gösterilmiştir. 


$$
\begin{aligned}
& S_{i}^{*}=\sqrt{\sum_{j=1}^{n}\left(v_{i j}-v_{j}^{*}\right)^{2}} \\
& S_{i}^{-}=\sqrt{\sum_{j=1}^{n}\left(v_{i j}-v_{j}^{-}\right)^{2}}
\end{aligned}
$$

Adım 6: İdeal Çözüme Göreli Yakınlığın Hesaplanması $\left(\mathrm{C}_{\mathrm{i}}^{*}\right)$

Karar noktalarından her birinin ideal çözüme göreli yakınlığının hesaplarken ideal ve negatif ideal ayırım ölçülerinden faydalanılır. İdeal çözüme göreli yakınlık değerinin hesaplanması aşağıdaki formülde gösterilmiştir.

$$
C_{i}^{*}=\frac{S_{i}^{-}}{S_{i}^{-}+S_{i}^{*}}
$$

Burada $\mathrm{C}_{\mathrm{i}}^{*}$ değeri $0 \leq \mathrm{Ci}^{*} \leq 1$ aralığında değer alır ve $\mathrm{C}_{\mathrm{i}}^{*}=1$ ilgili karar noktasının ideal çözüme, $C_{i}^{*}=0$ ilgili karar noktasının negatif ideal çözüme mutlak yakınlığını ifade etmektedir.

\subsection{VIKOR Yöntemi}

Aşağıda VIKOR yönteminin adımları verilmiştir.

Adım 1: Her bir değerlendirme kriteri için en iyi $\left(f_{i}^{*}\right)$ ve en kötü $\left(f_{i}{ }^{-}\right)$değerler belirlenir. $i=1,2, \ldots, \mathrm{n}$ için; (3.9) formülü kullanılır.

$f_{i}^{*}=\max _{j} f_{i j}, f_{i}^{-}=\min _{j} f_{i j}$

Adım 2:Her bir değerlendirme birimi için $S_{j}$ ve $R_{j}$ değerleri hesaplanır. $w_{i}$, kriter ağıllıklarını temsil etmektedir.

$$
\begin{aligned}
& S_{j}=\sum_{i=1}^{n} w_{i}\left(f_{i}^{*}-f_{i j}\right) /\left(f_{i}^{*}-f_{i}^{-}\right) \\
& \left.R_{j}=\max \left[w_{i} f_{i}^{*}-f_{i j}\right) /\left(f_{i}^{*}-f_{i}^{-}\right)\right]
\end{aligned}
$$

Adım 3: Her bir değerlendirme birimi için $Q_{j}$ değerleri hesaplanır.

$Q_{j}=v\left(S_{j}-S^{*}\right) /\left(S^{-}-S^{*}\right)+(1-v)\left(\left(R_{j}-R^{*}\right) /\left(R^{-}-R^{*}\right)\right)$

$S^{*}=\min _{j} S_{j} ; S^{-}=\max _{j} S_{j} ; R^{*}=\min _{j} R_{j} ; R^{-}=\max _{j} R_{j}$ değerlerini ifade etmektedir. $v$ değeri, grup faydasında maksimum strateji ağırlığını ifade etmek için kullanılırken, $(1-v)$ değeri ise karşıt görüştekilerin minimum pişmanlığının ağırlığını ifade etmektedir (Opricovic ve Tzeng, 2007). Literatürde $v$ değeri genellikle $v=0,5$ olarak kullanılır (Lixin vd., 2008; Wu vd., 2010). 
Yalova Sosyal Bilimler Dergisi

Adım 4: $Q_{j}, S_{j}, R$ değerlerinin sıralanmasıdır. En küçük Qj değerine sahip olmak alternatif grubu içerisindeki en iyi seçenek olduğunu belirtilmektedir.Elde edilen sonuçların geçerliliğin sağlanması için iki koşul bulunmaktadır. $\mathrm{Bu}$ koşullar sağlandığında, minimum $Q$ değerine sahip alternatif, en uygun olarak ifade edilebilmektedir.

Koşul 1 (C1) - Kabul edilebilir avantaj: En iyi ve en iyiye en yakın seçenek arasında belirgin bir fark olduğunu ifade eder.

$Q\left(P_{2}\right)-Q\left(P_{1}\right) \geq D(Q)$

Bu eşitsizlikte $P_{1}$, en düşük $Q$ değerine sahip olan birinci en iyi alternatif, $P_{2}$ ise en iyi ikinci alternatiftir. $D(Q)=1 /(j-1)$ şeklinde gösterilirkenj, değerlendirme birimi sayısını ifade etmektedir. Değerlendirme birimi sayısı 4 'ten küçük olduğu durumlarda $D(Q)=0,25$ alınmaktadır (Chen ve Wang, 2009).

Koşul 2 (C2) - Kabul edilebilir istikrar: En iyi $Q$ değerine sahip $P_{1}$ alternatifi $S$ ve $R$ değerlerinin az bir tanesinde en iyi skoru elde etmiş olması gerekmektedir. Belirtilen iki koşuldan bir tanesi sağlanmadığı durumlarda uzlaşık çözüme gidilmektedir:

2.Koşul sağlanmiyorsa $P_{1}$ ve $P_{2}$ alternatifleri,

1.Koşul sağlanmiyorsa $P_{1}, P_{2}, \ldots \ldots, P_{M}$ alternatifleri $Q\left(P_{M}\right)-Q\left(P_{1}\right) \geq D(Q)$ eşitsizliği dikkate alınarak ifade edilir. (Opricovic ve Tzeng, 2004).

\subsection{ELECTRE Yöntemi}

ELECTRE yöntemininin adımlarını şu şekilde özetleyebiliriz:

Adım 1: Karar matrisinin (A) oluşturulmas1

$A_{i j}$ matrisinde satırlarda yer alan m karar noktası sayısını, sütunlarda yer alan $\mathrm{n}$ ise değerlendirme faktörleri sayısını verir.

Adım 2:Standart karar matrisinin (X) oluşturulması

A matrisinin elemanları kullanılarak hesaplanan karar matrisinde maliyet ve fayda kriteri için farklı normalizsayon formülleri kullanılmaktadır. Maliyet kriteri için (3.14) formülü kullanılırken, fayda kriteri için (3.15) formülü kullanılmaktadır.

$$
x_{i j}=\frac{a_{i j}}{\sqrt{\sum_{k=1}^{m} a_{k j}^{2}}} \quad \mathrm{i}=1,2, \ldots, \mathrm{mj}=1,2, \ldots, \mathrm{n}
$$


Yalova Sosyal Bilimler Dergisi

$$
x_{i j}=\frac{1 / a_{i j}}{\sqrt{\sum_{k=1}^{m}\left(\frac{1}{a_{k j}}\right)^{2}}} \quad \mathrm{i}=1,2, \ldots, \mathrm{mj}=1,2, \ldots, \mathrm{n}
$$

Adım 3: Ağırlıklı standart karar matrisinin (Y) oluşturulması

Karar verici öncelikle değerlendirme faktörlerinin ağırlıklarını $\left(w_{i}\right)$ belirlenmektedir. Daha sonra X matrisinin her bir sütunundaki elemanlar ilgili $w_{i}$ değeri ile çarpılarak ağırlıklı standart karar matrisi (Y) oluşturulur.

Adım 4: Uyum ve uyumsuzluk setlerinin belirlenmesi

Y matrisinden yararlanılarak belirlenen uyum setlerinde her ikili alternatif kıyaslaması için kriterler iki ayrı kümeye ayrılmaktadır. $A_{p}$ ve $A_{q}(1,2, \ldots \mathrm{m}$ ve $p \neq$ q) uyum kümesinde $A_{p}, A_{q}$ 'ya tercih edilir.

$C_{(p, q)}=\left\{j, V_{p j} \geq V_{q i}\right\}$

$A_{p}, A_{q}$ 'dan daha kötü bir alternatif ise uyumsuzluk seti oluşturulur.

$D_{(p, q)}=\left\{j, V_{p j} \geq V_{q i}\right\}$

ELECTRE yönteminde uyum seti sayısı kadar uyumsuzluk seti sayısı vardır.

Adım 5: Uyum ve uyumsuzluk indekslerinin hesaplanması

Uyum matrisinin (C) oluşturulması için uyum ve uyumsuzluk setlerinden yararlanılır. C matrisinin elemanları aşağıdaki formülde gösterilen ilişki yardımıyla hesaplanır.

$$
C_{p q}=\sum_{j^{*}} w_{j^{*}}
$$

Örneğin $\mathrm{C}_{12}=\{1,4\}$ ise, $\mathrm{C}$ matrisinin $c_{12}$ elemanının değeri $c_{12}=w_{1}+w_{4}$ olacaktır. Uyumsuzluk matrisinin (D) elemanları ise aşağıdaki formül yardımıyla hesaplanır:

$$
d_{k l}=\frac{\max \left|y_{k j}-y_{l j}\right|}{\max \left|y_{k j}-y_{l j}\right|}
$$

Adım 6: Üstünlük karşılaştırmasının yapılması 
Yalova Sosyal Bilimler Dergisi

Uyum üstünlük matrisi $(\mathrm{F}) \mathrm{m} \times \mathrm{m}$ boyutludur ve matrisin elemanları uyum eşik değerinin $(\bar{C})$ uyum matrisinin elemanlarıyla $\left(C_{p q}\right)$ karşılaştııılmasından elde edilir. Uyum eşik değeri $(\bar{C})$ aşağıdaki formül yardımıyla elde edilir.

$\bar{C}=\frac{1}{m(m-1)} \sum_{p}^{m} \sum_{q}^{m} C_{p q}$

Ĕger $c_{p q} \geq \bar{C}$ ise $f_{p q}=1$, eğer $c_{p q} \leq \bar{C}$ ise $f_{p q}=0$ ' dir.

Uyumsuzluk üstünlük matrisi $(\mathrm{G})$ de $\mathrm{m} \times \mathrm{m}$ boyutludur ve $\mathrm{F}$ matrisine benzer şekilde oluşturulur. Uyumsuzluk eşik değeri $(\bar{D})$ aşağıdaki formül yardımıyla elde edilir:

$\bar{D}=\frac{1}{m(m-1)} \sum_{p}^{m} \sum_{q}^{m} D_{p q}$

Eğer $d_{p q} \geq \bar{D}$ ise $g_{p q}=1$, eğer $d_{p q} \leq \bar{C}$ ise $g_{p q}=0$ ' dır.

Adım 7: Toplam baskınlık matrisinin oluşturulması

Toplam baskınlık matrisinin (E) elemanları $\left(e_{p q}\right)$ aşağıdaki formülde gösterildiği gibi $f_{p q}$ ve $g_{p q}$ elemanlarının karşılıklı çarpımına eşittir.

$e_{p q}=f_{p q} * g_{p q}$

\section{Literatür Taraması}

Acar (2003) tarımsal işletmelerin finansal performans değerlendirmesini nasıl yapılacağına ve nasıl analiz edileceğine dair bir çalışma yapmıştır. Albayrak ve Erkut (2005) hizmet sektöründe yaptıkları uygulama ile finansal olan ve finansal olmayan ölçütleri bir arada değerlendirme imkânı veren bir değerlendirme modeli kurmuşlardır. AHP yöntemini kullanarak sosyal kriterlerinde performans değerlendirmede etkili olduğunu kanıtlamışlardır. Eleren ve Karagül (2008), TOPSIS yöntemini kullanarak 1986-2006 dönemindeki 7 ekonomik gösterge değerlendirilerek Türkiye ekonomisinin performansını incelemişlerdir. Yalama ve Sayım (2008) imalat sektöründeki şirketlerin Veri Zarflama Analizi yardımıyla performanslarını karşılaştırmışlardır ve ortalama etkinlik skorunu hesaplamışlardır. Bülbül ve Köse (2009), TOPSIS ve ELECTRE yöntemlerini gida sektöründe bulunan sektörleri ve şirketleri finansal performansları açısından değerlendirmek için kullanmışlardır. Nesrin ve Alptekin (2009), çalışmalarının amacı yatırım fonlarının performansını değerlendirmektir. Bu amacı gerçekleştirmede TOPSIS yöntemi kullanarak 6 adet performans tekniğinin sonuçlarını tek bir skora indirmişlerdir. Demireli (2010), çok ölçütlü karar verme yöntemlerinden TOPSI yöntemini kullanarak kamu bankalarının performanslarını değerlendirip bir sıralama yapmışlardır. Dumanoğlu (2010), 2004-2009 yılları arasındaki mali tabloları kullanarak İMKB'deki 15 çimento işletmecinin finansal oranlarını TOPSIS yöntemi ile elde etmiştir. Özer vd. (2010), TOPSIS, Veri Zarflama Analizi 
Yalova Sosyal Bilimler Dergisi

ve Kümeleme yöntemlerini entegre halde kullanarak sonuçlarını karşılaştırmışlardır. Akyüz vd. (2011), seramik sektöründe faaliyet gösteren ve İMKB'de yer alan bir işletmenin 10 yıllık finansal performansını incelemişlerdir.

Atmaca (2012) belirli bir dönem aralı̆̆ında TOPSIS yöntemini kullanarak spor hizmet şirketlerinin finansal performanslarını karşılaştırmalı olarak analiz etmiştir. Bulgurcu (2012), 2009-2011 yılları arasındaki mali performanslarının bulunduğu İMKB'den 13 teknoloji firmasının 10 adet finansal oranını kullanarak TOPSIS yöntemi ile skorlandırmıştır. Uygurtürk ve Korkmaz (2012), IMMKB'deki 13 ana metal sanayi işletmesinin belirli dönemlerdeki finansal performanslarını TOPSIS yöntemi ile değerlendirmişlerdir. Türkmen ve Çağıl (2012), 12 işletmenin 3 yıllık bir dönemdeki finansal oranlarının TOPSIS yönteminde veri seti olarak kullanmışlardır. Yayar ve Baykara (2012), Türkiye'deki katılım bankalarının performansını belirlemek üzere yaptıkları çalışmada, banka finansal performans göstergelerini etkinlik ve verimlilik başlıkları altında ayrı ayrı göstermişlerdir. Hosseini vd. (2013), Tahran Borsasında 2009-2011 y1lları arasında en iyi performans değerine sahip işletmelerin finansal oranlarının AHP-TOPSIS yöntemleriyle elde edilen skorlarını karşılaştırmak üzere bir çalışma yapmışlar. Çalışmalarında, likidite, faaliyet, finansal yapı ve karlılık gibi oranları TOPSIS ve AHP yönteminde veri olarak kullanmışlardır. Ömürbek ve Kınay (2013) TOPSIS yöntemini kullanarak havayolu taşımacılığ sektöründe hizmet veren BIST ve XYZ'de yer alan firmaların finansal performanslarının karşılaştırmalı analizini yapmışlardır. Aynı zamanda çalışma içerisinde kullanılan yöntemler farklı karar verme problemlerinde uygulanma imkânı bulan ve çeşitli ölçütlere göre analizler yapan çok ölçütlü karar verme yöntemleridir. Bu yöntemler literatürde çeşitli alanlar ve başlıklar altında incelenmiştir. Bu çalışmalardan bazıları;

Bedir ve Eren (2015) AHP ve Promethee yöntemlerini birlikte kullanarak perakendecilik sektöründe personel seçiminde, İnce vd. (2016) AHP yöntemi il hizmet sektöründe talebi etkileyen faktörlerin değerlendirilmesinde, Özder vd. (2015) TOPSIS yöntemini tedarik zinciri yönetimi konusu altında tedarikçi seçiminde, Ayan vd. (2016) AHP ve TOPSIS yöntemlerinin entegre halini ekokardiografi cihazı seçiminde, Geyik vd. (2016) AHP ve TOPSIS yöntemlerini kitap basım evi seçiminde, Alp ve Engin (2016) trafik kazalarının nedenleri ve sonuçları arasındaki ilişkileri değerlendirmede çok ölçütlü karar verme yöntemlerini kullanmışlardır. Çalışkan ve Eren (2016) çok ölçütlü karar verme yöntemlerini kullanarak bankaların performanslarını değerlendirmişlerdir. Mermi vd. (2016) TOPSIS yöntemini kullanarak ana haber bültenlerinin analizini yapmışlardır. Demirci vd. (2017) BIST’te belli bir sektöre ait işletmelerin finansal performanslarına optimizasyon modeli geliştirmişlerdir. Oyun teorisi ile portföy yönetiminde analizler yapmışlardır. Bedir vd. (2017) çalışmalarında çok ölçütlükarar verme yöntemlerinden AHP yöntemi ile entegre yöntem kullanarak demontaj hattı dengeleme uygulaması yapmışlardır.

\section{Uygulama}

Uygulamanın amac1 otomotiv imalat sektöründe faaliyet gösteren işletmeler üzerinde AHP, TOPSIS, ELECTRE ve VIKOR yöntemleri kullanılarak elde edilen 
Yalova Sosyal Bilimler Dergisi

skorların nasıl sonuç verdiklerini görmektir. Bu kapsamda ilk olarak Borsa İstanbul'da 2011-2015 yılları arası işlem gören otomotiv sektöründeki 11 firmanın mali oranlarının veri olarak kullanıldığ üç uygulama yapılmıştır.

\section{1. İlk Uygulama}

Çalışmada veri seti olarak İstanbul sanayi odasının verilerine göre Türkiye'deki ilk 500 işletme arasından ve BIST-100 kapsamında yer alan otomotiv sektöründe faaliyet gösteren on bir işletme seçilmiştir. İlgili işletmelerin finansal tabloları kamu aydınlatma platformu resmi internet sayfası aracılığıyla 2011-2015 yılları arasında 5 yıl olarak incelemeye dâhil edilmiştir. Veri seti edinilirken inceleme aşamasında Türkiye'deki ilk 500 işletme içerisinde olup finansal tablolarında süreklilik olmayan, eksiklik bulunan, BİST-100 endeksinde yer almayan ve aynı sektörde bulunmayan işletmeler kapsam dışında bırakılmıştır. Bu koşulu sağlayan 11 adet işletme ve kodları Tablo 1'de gösterilmektedir.

Oran analizi hesaplarken işletmelerdeki mali bilgilerini içeren bilanço ve gelir tablosu kullanılarak yapılmaktadır. Yapılan analizlerde finansal tablolar içindeki birbirleri ile ilişkili kalemlerin oran şeklinde ifade edildiği gösterilmektedir. Elde edilen bu oranların daha sonra işletmelerin faaliyetleri ile finansal durumları göz önünde bulundurulacak şekilde sınıflandırılması yapılmaktadır. Bu sınıflandırmaya göre oranlar; likidite oranları, finansal yapı oranları, faaliyet oranları, karlılık oranları olarak ele alınmıştır. Çalışmada kullanılacak olan oranlar ve oranlara ait kodlar Tablo 2'de gösterilmiştir.

Tablo 1: BİST-100' de Yer Alan İmalat Sanayi İşletmeleri

\begin{tabular}{ll}
\hline Kod & BİST 100 de Yer Alan İmalat Sanayii İşletmeleri \\
\hline F1 & Anadolu Isuzu Otomotiv Sanayi ve Ticaret A.Ş. \\
F2 & Bosh Fren Sistemleri Sanayi Ticaret A.Ş. \\
F3 & DİTAŞ Doğan Yedek Parça İmalat ve Teknik A.Ş. \\
F4 & Ege Endüstri ve Ticaret A.Ş. \\
F5 & Federal-Mogul İzmit Piston ve Pim Üretim Tesisleri A.Ş. \\
F6 & Ford Otomotiv Sanayi A.Ş. \\
F7 & Karsan Otomotiv Sanayi ve Ticaret A.Ş. \\
F8 & Katmerciler Araç Üstü Ekipman Sanayi ve Ticaret A.Ş. \\
F9 & Otokar Otomotiv ve Savunma Sanayi A.Ş. \\
F10 & Persan Makine Parçaları Sanayi A.Ş. \\
F11 & Tofaş Türk Otomobil Fabrikasi A.Ş. \\
\hline
\end{tabular}

Tablo 2: Finansal Oranlar ve Kodları

\begin{tabular}{ll}
\hline Finansal Oranlar & Kod \\
\hline Cari Oran & L1 \\
Likidite Oranı & L2 \\
Toplam Borçlar / Toplam Pasifler & FY1 \\
Maddi Duran Varlıklar (Net) / Öz kaynaklar & FY2 \\
Net Satışlar / Toplam Aktifler & F01 \\
Net Satışlar / Duran Varlıklar (Net) & F02 \\
Dönem net kârı / Net Satışlar & K01 \\
Dönem net kârı / Öz kaynaklar & K02 \\
Dönem net kârı / Toplam Aktifler & K03 \\
\hline
\end{tabular}


Yalova Sosyal Bilimler Dergisi

\section{Cari Oran}

Cari oran işletmelerin çalışma sermayesine sahip olup olmadığını göstermekte ve brüt işletme sermayesinin (dönen varlıklar) kısa vadeli borçlara bölünmesi ile hesaplanmaktadır. Cari oran işletmelerin likidite seviyesi ve borç ödeme gücü yeterliliğini göstermektedir.

\section{Likidite Oranı}

Cari orana göre daha hassas likidite ölçümü veren bir orandır. Dönen varlıklardan işletmenin stokları düşüldükten sonra kalan tutarın kısa vadeli borç toplamına bölünmesi ile bulunur. Bu oranın kullanılmasının ardında stokların paraya en geç çevrilebilen dönen varlık kalemi olması düşüncesi bulunmaktadır. Oranla stoklar düştükten sonra kalan likiditenin işletmenin kısa vadeli borçlarını ödeyip ödeyemediği sorusuna cevap aranır.

\section{Toplam Borçlar/Toplam Pasifler}

Toplam borçların toplam pasiflere bölünmesi ile bulunan ve kaldıraç oranı olarak da nitelendirilen bu oran işletmelerin toplam kaynaklarının diğer bir açıdan toplam varlıklarının ne kadarlık bir kısmının borçla finanse edildiğini gösterir. $\mathrm{Bu}$ oranın \%50'nin altında olması işletmeler için olumludur. Oranın küçük olması güçlü bir mali yapıyı ifade eder.

\section{Maddi Duran Varlıklar(Net)/Özkaynaklar}

Maddi duran varlıkların özkaynaklara bölünmesi ile bulunan bu oran maddi duran varlıkların finansmanında öz sermayenin ne oranda kullanıldığını ifade eder. Oranın 1'den büyük çıkması duran varlıkların finansmanında borç kullanıldığını 1'den küçük çıkması ise duran varlıkların tamamen özkaynaklarla finanse edildiğini ifade eder.

\section{Net Satışlar/Toplam Aktifler}

İşletmedeki varlık kalemlerinin net satışlar kalemine oranlanması ile işletmedeki aktif varlıkların verimliliği ölçülmektedir. Bu oran toplam aktiflerin işletmede ne ölçüde verimli kullanıldığını gösteren orandır. Verimlilik oranları ne kadar yüksek çıkarsa işletme açısından o derece olumludur. Yüksek bir aktif devir hızı işletmenin aktiflerini verimli kullandığını gösterir.

\section{Net Satışlar/Duran Varlıklar(Net)}

Net satışların net maddi duran varlıklara bölünmesi ile bulunan bu oran maddi duran varlıkların devir hızını diğer bir ifade ile verimliliğini ölçer. Oran 1' in altında olursa işletmenin maddi duran varlıkları kadar dahi satış yapamadığını 
Yalova Sosyal Bilimler Dergisi

gösterirken, oranın 1'den daha yüksek çıkması maddi duran varlıkları aşan miktarda satış yapıldığını göstermektedir.

\section{Dönem Net Karı/Net Satıșlar}

Satışlara ilişkin karlılık oranları, ilgili kalemlerin dönem karlılık rakamlarına bölünmesi ile bulunmaktadır. İşletmenin karlılık oranları işletmenin başarısını ölçen oranlar olarak da ifade edilmektedir. Dönem net karı/ net satışlar oranı işletmenin net satışlarının ne kadarının işletmede kaldığını gösteren bir orandır. Net kar rakamı giderler ve vergi sonrası karı ifade ettiği için nihai olarak işletmenin başarısını ifade etmektedir.

\section{Dönem Net Karı/Özkaynaklar}

Dönem net karının özkaynaklara bölünmesi ile bulunan bu oran işletme ortaklarının koymuş olduğu sermayenin ne kadar verimli kullanılıp kullanılmadığını gösterir. Diğer bir ifade ile bir liralık bir özkaynağın ne kadar kar oluşturduğunu veren bir orandır. İşletme ortakları ve yatırımcılar bu oranı alternatif firsatlar ile birlikte değerlendirerek yorumlamaktadırlar.

\section{Dönem Net Karı/Toplam Aktifler}

Dönem net karının toplam aktiflere bölünmesi ile bulunan bu oran işletmenin özkaynakları ve yabanc1 kaynakları ile oluşturduğu toplam aktiflerinin ne kadar verimli kullanılıp kullanılmadığı konusunda bilgi vermektedir (Akgüç,1995)

Uygulamada kullanılacak olan verilerin ağırlıkları AHP yöntemiyle belirlenmiştir. Kriterlere ilişkin karşılaştırma matrisi oluşturulurken çeşitli literatür taramaları yapılmış ve uzman görüşleri alınmıştır. Bu görüşlerin tek bir değer olarak ifade edilmesi üzerine geometrik ortalamaları alınmıştır. Alınan uzman görüşleri ve yapılan literatür taramalarına göre uygulamada kullanılan kriterlere ait ikili karşılaştırma matrisi Tablo3'te gösterilmiştir.

Tablo 3 kullanılarak AHP adımlarından ikinci adımı uygulanarak karar matrisinin satır toplamları normalize edilmiştir. Kriterlerin ağırlıkları hesaplanmış ve Tablo 4'te gösterilmiştir.

İkili karşılaştırma matrisinin en büyük özdeğeri olan $\lambda_{\max }$, EXCEL programı kullanılarak hesaplanmış ve 9,81 bulunmuştur. Buna bağlı olarak tutarlılık göstergesi $(C I)$ ve tutarlılık oranı $(R I)$ aşağıdaki şekilde hesaplanmıştır.

$$
\begin{aligned}
& C I=\frac{\lambda \max -n}{n-1}=\frac{9,81-9}{9-1}=0,10, \\
& C R=\frac{C I}{R I}=\frac{0,10}{1,45}=0,069
\end{aligned}
$$


Yalova Sosyal Bilimler Dergisi

Tablo 3: Kriterlere İlişkin İkili Karşılaştırma Matrisi

\begin{tabular}{llllllllll}
\hline Kriterler & L1 & L2 & FY1 & FY2 & F01 & F02 & K01 & K02 & K03 \\
\hline L1 & 1 & 3,277 & 0,70 & 1,440 & 0,790 & 0,790 & 0,560 & 0,966 & 0,677 \\
L2 & 0,305 & 1 & 0,333 & 0,666 & 0,575 & 0,695 & 0,560 & 1,5 & 0,790 \\
FY1 & 1,429 & 3,003 & 1 & 1 & 0,500 & 0,440 & 0,560 & 0,790 & 1,220 \\
FY2 & 0,694 & 1,502 & 1 & 1 & 0,575 & 0,630 & 0,790 & 0,465 & 1 \\
FO1 & 1,266 & 1,739 & 2 & 1,739 & 1 & 1 & 0,790 & 0,930 & 1,050 \\
F02 & 1,266 & 1,439 & 2,273 & 1,587 & 1 & 1 & 0,966 & 1 & 0,500 \\
K01 & 1,786 & 1,786 & 1,786 & 1,266 & 1,266 & 1,035 & 1 & 0,500 & 1,540 \\
K02 & 1,035 & 0,667 & 1,266 & 2,151 & 1,075 & 1 & 2 & 1 & 2,070 \\
K03 & 1,477 & 1,266 & 0,820 & 1 & 0,952 & 2 & 0,649 & 0,483 & 1 \\
\hline
\end{tabular}

Tutarlılık oranı $(C R)$ değeri $0,1^{\prime}$ 'den küçük olduğundan karar vericilerin değerlendirmelerinin tutarlı olduğu söylenebilir.

Tablo 4: Kriterleri Normalize Edilmiş, Tüm Uygulamalarda Kullanılan Veriler ve Ağırlık Değerleri

\begin{tabular}{lll}
\hline Finansal Oranlar & Kod & Veri Ağırlık \\
\hline Cari Oran & L1 & 0,11 \\
Likidite Oranı & L2 & 0,08 \\
Toplam Borçlar / Toplam Pasifler & FY1 & 0,10 \\
Maddi Duran Varlıklar (Net) / Öz kaynaklar & FY2 & 0,08 \\
Net Satışlar / Toplam Aktifler & F01 & 0,13 \\
Net Satışlar / Duran Varlıklar (Net) & F02 & 0,12 \\
Dönem net kârı / Net Satışlar & K01 & 0,13 \\
Dönem net kârı / Öz kaynaklar & K02 & 0,14 \\
Dönem net kârı / Toplam Aktifler & K03 & 0,11 \\
\hline
\end{tabular}

Tablo 5: Karar Matrisi

\begin{tabular}{l|lllllllll}
\hline Alternatif/Kriter & L1 & L2 & FY1 & FY2 & F01 & F02 & K01 & K02 & K03 \\
\hline F1 & 0,833 & 0,469 & 1,171 & 0,320 & 1,062 & 6,344 & 0,019 & 0,055 & 0,020 \\
F2 & 0,805 & 0,736 & 0,270 & 0,002 & 1,239 & 6,354 & 0,149 & 0,253 & 0,185 \\
F3 & 1,620 & 1,091 & 0,636 & 0,937 & 1,167 & 3,317 & $-0,003$ & $-0,011$ & $-0,004$ \\
F4 & 5,549 & 4,578 & 0,268 & 0,118 & 1,145 & 6,555 & 0,325 & 0,508 & 0,372 \\
F5 & 9,199 & 8,512 & 0,095 & 0,216 & 1,276 & 4,858 & 0,270 & 0,381 & 0,345 \\
F6 & 1,054 & 0,793 & 3,473 & 1,062 & $-1,766$ & $-3,385$ & 0,050 & 0,275 & 0,100 \\
F7 & 1,020 & 0,774 & 0,855 & 1,863 & $-0,541$ & $-0,813$ & $-0,068$ & $-0,290$ & $-0,042$ \\
F8 & 1,595 & 1,058 & 0,726 & 0,534 & 1,359 & 6,035 & 0,060 & 0,297 & 0,081 \\
F9 & 1,299 & 0,754 & 0,847 & 0,423 & 0,893 & 2,450 & 0,055 & 0,324 & 0,050 \\
F10 & 1,037 & 0,621 & 0,403 & 1,207 & 0,247 & 0,283 & 0,111 & 0,046 & 0,027 \\
F11 & 1,150 & 1,029 & 0,738 & 0,818 & 1,005 & 2,129 & 0,084 & 0,322 & 0,084 \\
\hline
\end{tabular}

Tutarlılık tespit edildikten sonra Tablo 4'teki ağırlıklar kullanılarak daha önce belirtilen TOPSIS yöntemiyle problem çözülmüştür. Bu çalışmada ise sadece 2015 yılına ilişkin çözüm gösterilecek olup diğer yılların da çözüm aşamaları buna 
Yalova Sosyal Bilimler Dergisi

benzer olduğu için yalnızca sonuçlarına yer verilecektir. Verilerden elde edilmiş olan karar matrisi Tablo5'de gösterilmiştir.

Tablo 6: 2015 Yılına Ait Verilere Göre İşletmelerin TOPSIS Sıralaması

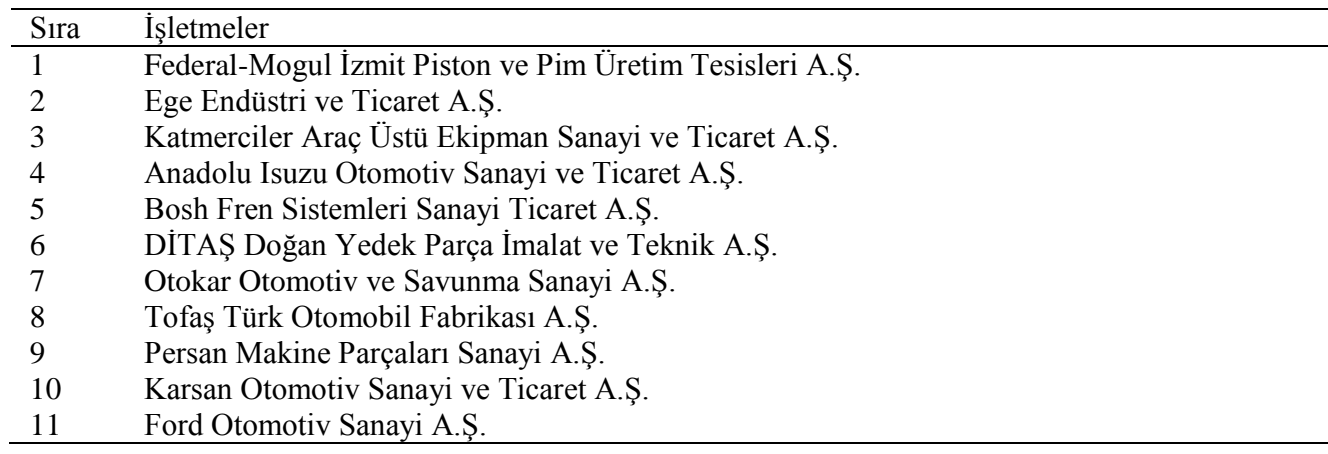

Karar vericiler tarafından oluşturulan karar matrisi TOPSIS yönteminin adımlarına göre analiz edilerek hesaplama işlemleri yapılmıştır. Yöntem adımları tek tek uygulanarak 2015 yılına ait hesaplamalar sonucu oluşan TOPSIS sıralaması Tablo 6 'de gösterilmiştir. Bu şekilde diğer yıllara ait veriler kullanılarak 5 yıllık getiri sıralaması aynı işlemlerin uygulanması sonucu bulunmuştur. Tablo 7'de 2011-2015 yılları arasında BISST-100 de işlem gören otomotiv imalat sanayi işletmelerinden kendi içinde yatırımcısına en iyi getiriyi sağlayan ilk 11 işletme 5 yıla ilişkin topyekûn olarak gösterilmiştir. Tüm yıllara ilişkin genel sıralama tablolarında firmaları ifade etmek için isimlerinden ziyade kodları kullanılmıştır. Sonuçlara bakıldığında 2014 yılı hariç diğer yıllarda F5 firmasının en yüksek performansa sahip olduğu görülmektedir. 2014 yılında ise F4 firması birinci olmuştur. $\mathrm{Bu}$ değerlerde etkili olan en önemli kriterler AHP yöntemi ile ağırlıklandırılarak siralama oluşturulmuştur. Bu sıralamada önemli bir değere sahip olan dönem net kâr1/özkaynaklar kriteri bakımından uygun olan firmalar gösterilmiştir.

\section{2. İkinci Uygulama}

Uygulamada TOPSIS çözümünde olduğu gibi kriterlere karşılık gelen sayısal veriler net olarak elde edinilebildiğinden kriter ağırlıklandırılmasında AHP metodu kullanılmıştır. $\mathrm{Bu}$ yöntemle kriter ağırlıkları belirlenmiş, sonrasında bu ağırlıklar VIKOR tekniğinde kullanılmıştır. Bu uygulamanın sonunda VIKOR yöntemi ile analiz edilecek olan firmalar, kriterler ve 2011-2015 yıllarına ait veriler kapsamında değerlendirilmiştir. Bu bölümde ise sadece 2011 yılına ilişkin çözüm gösterilecek olup diğer yılların da çözüm aşamaları buna benzer olduğu için yalnız sonuçlarına yer verilecektir. 2011 yılına ait karar matrisi dikkate alınarak tüm performans ölçme birimlerinin her bir kriter kapsamında en iyi en kötü değerleri belirlenmiştir. Bu değerler Tablo 8'de gösterilmiştir. 
Yalova Sosyal Bilimler Dergisi

Tablo 7:İşletmelerin AHP Ağırlıklandırılması Kullanılarak Getirilerin TOPSIS Sıralaması

\begin{tabular}{llllll}
\hline Siralama/Y1 & 2011 & 2012 & 2013 & 2014 & 2015 \\
\hline 1 & F5 & F5 & F5 & F4 & F5 \\
2 & F6 & F1 & F1 & F5 & F4 \\
3 & F1 & F2 & F2 & F3 & F8 \\
4 & F4 & F3 & F6 & F2 & F1 \\
5 & F3 & F8 & F3 & F1 & F2 \\
6 & F2 & F6 & F8 & F8 & F3 \\
7 & F8 & F4 & F11 & F11 & F9 \\
8 & F9 & F11 & F9 & F9 & F11 \\
9 & F7 & F9 & F7 & F10 & F10 \\
10 & F11 & F7 & F10 & F7 & F7 \\
11 & F10 & F10 & F4 & F6 & F6 \\
\hline
\end{tabular}

Tablo 8: Kriterler İçin 2011 Yılına Ait En İyi ve En Kötü Değerler

\begin{tabular}{llllllllll}
\hline Alternatif/Kriter & L1 & L2 & FY1 & FY2 & FO1 & FO2 & KO1 & KO2 & KO3 \\
\hline F1 & 1,590 & 0,810 & 0,500 & 0,350 & 1,340 & 5,640 & $-0,030$ & 0,076 & 0,038 \\
F2 & 0,890 & 0,830 & 0,940 & 2,690 & 0,810 & 4,450 & $-0,030$ & 0,400 & 0,020 \\
F3 & 2,110 & 1,300 & 0,370 & 0,440 & 1,600 & 4,800 & 0,030 & 0,080 & 0,050 \\
F4 & 2,050 & 1,300 & 0,560 & 0,380 & 1,120 & 4,950 & 0,170 & 0,420 & 0,190 \\
F5 & 17,64 & 16,27 & 0,050 & 0,130 & 1,220 & 8,500 & 0,260 & 0,330 & 0,310 \\
F6 & 1,290 & 0,870 & 0,570 & 0,580 & 2,360 & 7,840 & 0,060 & 0,350 & 0,150 \\
F7 & 0,740 & 0,550 & 0,670 & 1,580 & 1,710 & 2,840 & $-0,040$ & $-0,220$ & $-0,071$ \\
F8 & 1,220 & 0,410 & 0,750 & 0,610 & 0,730 & 3,270 & 0,030 & 0,080 & 0,020 \\
F9 & 1,050 & 0,740 & 0,750 & 0,530 & 1,040 & 3,190 & 0,060 & 0,260 & 0,060 \\
F10 & 2,100 & 1,210 & 0,170 & 0,590 & 0,530 & 0,730 & 0,200 & 0,130 & 0,110 \\
F11 & 1,300 & 1,160 & 0,720 & 0,730 & 1,160 & 2,680 & 0,060 & 0,260 & 0,080 \\
\hline $\mathrm{fi}^{*}$ & 17,64 & 16,27 & 0,940 & 2,690 & 2,360 & 8,500 & 0,260 & 0,420 & 0,310 \\
$\mathrm{f}_{\mathrm{i}}{ }^{-}$ & 0,740 & 0,410 & 0,050 & 0,130 & 0,530 & 0,730 & $-0,040$ & $-0,220$ & $-0,071$ \\
\hline
\end{tabular}

Her bir kriter bazında değerlendirilerek belirlenen en iyi ve en kötü değerler uygulanan yöntemin diğer bir adımına göre işlem görmüş ve $S, R, Q$ değerlerinin küçükten büyüğe doğru sıralaması Tablo 9'da verilmiştir.

Tablo 9: S, R Ve Q Değerlerinin Küçükten Büyüğe Doğru Sıralanması

\begin{tabular}{llllllllllll}
\hline \multicolumn{2}{l}{ Siralama } \\
\hline Sj & S5 & S6 & S4 & S2 & S11 & S9 & S3 & S1 & S10 & S8 & S7 \\
Rj & R3 & R4 & R1 & R5 & R11 & R6 & R9 & R2 & R8 & R10 & R7 \\
Qj & Q5 & Q6 & Q4 & Q2 & Q3 & Q11 & Q9 & Q1 & Q8 & Q10 & Q7 \\
\hline
\end{tabular}

Sıralama işlemi yapıldıktan sonra koşulların kontrol edilmesi gerekmektedir.

Koşul 1: Performans açısından birinci ve ikinci sıradaki birimlerin farkı alınmalı ve alternatif sayısına bağlı bir hesaplama yapılmalıdır. Alternatif sayısı 11 olduğu için $D(Q)=\frac{1}{j-1}$ formülü yardımıyla $D(Q)=0,1$ olarak bulunmuştur.

$Q\left(P_{2}\right)-Q\left(P_{1}\right) \geq D(Q)$ eşitliğini incelemek gerekmektedir. $v=0,5 \mathrm{Kabul}$ edildiğinde ikinci sıradaki alternatif $Q\left(P_{2}\right)=Q_{6}$, birinci sıradaki alternatif ise 
Yalova Sosyal Bilimler Dergisi

$Q\left(P_{1}\right)=Q_{5}$ olmaktadır. $Q_{6}=0,224471 . Q_{5}=0,054246$ şeklinde bulunmuştur. Dolayısıyla $Q_{6}-Q_{5}=0,170225 \geq 0,1$ olduğundan koşul 1 sağlanmıştır.

Koşul 2: $Q_{5}$, $\mathrm{S}$ ve $\mathrm{R}$ değerlerinden en az bir tanesinde en iyi skoru elde ettiğinden koşul 2 de sağlanmıştır. Bu durumda tüm kriterler açısından en iyi skoru $Q_{5}$ elde etmiştir. Onu $Q_{6}$ ve $Q_{4}$ takip etmiştir. Kodların karşılığı olan firmalar ise; 1 . Sırada Federal-Mogul İzmit Piston ve Pim Üretim Tesisleri A.Ş, 2.sırada Ford Otomotiv Sanayi A.Ş., 3.sırada ise Ege Endüstri ve Ticaret A.Ş.' tir. Bu şekilde VIKOR yönteminin adımları ve kontrol koşulları tüm kriter ve alternatifler için diğer yıllara da uygulanmıştır. Tüm yıllara ait firmaların VIKOR skorlarına göre en iyiden en kötüye sıralaması Tablo 10’ da gösterilmiştir.

Tablo 10 incelendiğinde 2011 ve 2012 yıllarında F5 firmasının TOPSIS yönteminde olduğu gibi birinci olduğu görülmektedir. 2013 yılında ise F1 firması en üst sırada yer alırken 2014 yılında yine TOPSIS sonuçlarında olduğu gibi F4 firması en iyi performansa sahip olmuştur ve 2015 yılında TOPSIS yönteminden farklı olarak birinci olmuştur. Genellemeye bakılarak en kötü performansın VIKOR yöntemine göre F7 firmasına ait olduğu tespit edilmiştir.

Tablo 10: VIKOR Yöntemine Göre 2011-2015 Yılları Arasındaki Performans Sıralaması

\begin{tabular}{llllll}
\hline SIRA/YIL & 2011 & 2012 & 2013 & 2014 & 2015 \\
\hline 1 & F5 & F5 & F1 & F4 & F4 \\
2 & F6 & F2 & F4 & F5 & F5 \\
3 & F4 & F6 & F5 & F3 & F8 \\
4 & F2 & F4 & F2 & F8 & F11 \\
5 & F3 & F11 & FF6 & F11 & F2 \\
6 & F11 & F9 & F3 & F9 & F9 \\
7 & F9 & F1 & F11 & F2 & F3 \\
8 & F1 & F8 & F9 & F10 & F1 \\
9 & F8 & F3 & F7 & F1 & F10 \\
10 & F10 & F10 & F10 & F6 & F6 \\
11 & F7 & F7 & F8 & F7 & F7 \\
\hline
\end{tabular}

\section{3. Üçüncü Uygulama}

ELECTRE yönteminin kullanılma nedeni çalışmaya zenginlik katarak birden fazla çözüm yöntemi ile elde edilen sonuçların daha tutarlı ve doğru bir sonuç verecek olmasıdır. Bu bölümde ise sadece 2013 yılına ilişkin çözüm gösterilecek olup diğer yılların da çözüm aşamaları buna benzer olduğu için yalnız sonuçlarına yer verilecektir.

Kriterlerin ve alternatiflerin değerlendirildiği 2013 yılına ait karar matrisi Tablo 11'de gösterilmiştir.

ELECTRE yönteminin adımlarına göre ağırlıklı normalize karar matrisindeki veriler kullanılarak uyum ve uyumsuzluk kümeleri oluşturulmuştur. Uyum ve uyumsuzluk setleri belirlendikten sonra, bu setlere göre uyum ve uyumsuzluk indeksleri bulunmuştur. Bu indekslere baz alınarak uyum (C) ve uyumsuzluk (D) matrisleri hesaplanmıştır. Uyum ve uyumsuzluk matrislerindeki verilerden 
Yalova Sosyal Bilimler Dergisi

yararlanılarak uyum eşik ve uyumsuzluk eşik değerleri hesaplanmıştır. Buna göre uyum eşik değeri $\bar{C}=0,5$, uyumsuzluk eşik değeri $\bar{D}=0,512126484$ olarak bulunmuştur. Uyum matrisi ve uyum eşik değerinden yararlanarak uyum üstünlük matrisi (F) hesaplanmıştır. Uyumsuzluk matrisi ve uyumsuzluk eşik değeri kullanılarak uyumsuzluk üstünlük matrisi $(\mathrm{G})$ bulunmuştur. Uyum üstünlük $(\mathrm{F})$ ve uyumsuzluk üstünlük $(\mathrm{G})$ matrislerinden yararlanılarak toplam baskınlık matrisi (E) bulunmuştur.

Tablo 11: 2013 yılına ait verilerden elde edilen karar matrisi

\begin{tabular}{llllllllll}
\hline Alternatif/Kriter & L1 & L2 & FY1 & FY2 & FO1 & FO2 & KO1 & KO2 & KO3 \\
\hline F1 & 2,326 & 1,705 & 0,436 & 0,178 & 0,995 & 6,923 & 0,308 & 0,544 & 0,307 \\
F2 & 2,819 & 2,626 & 0,317 & 0,269 & 1,112 & 5,849 & 0,125 & 0,204 & 0,139 \\
F3 & 1,945 & 1,305 & 0,484 & 0,470 & 1,213 & 4,632 & 0,075 & 0,176 & 0,091 \\
F4 & 3,321 & 2,406 & 0,321 & 0,233 & $-0,905$ & $-3,664$ & 0,170 & 0,318 & 0,216 \\
F5 & 10,355 & 9,681 & 0,076 & 0,283 & 1,166 & 3,877 & 0,204 & 0,258 & 0,238 \\
F6 & 1,019 & 0,784 & 8,150 & 0,998 & 1,904 & 3,215 & 0,019 & 0,098 & 0,037 \\
F7 & 2,012 & 1,578 & 0,677 & 0,887 & 0,885 & 1,557 & 0,005 & 0,013 & 0,004 \\
F8 & 1,224 & 0,723 & 0,863 & 0,755 & 0,614 & 4,009 & 0,071 & $-0,243$ & $-0,033$ \\
F9 & 1,161 & 0,728 & 0,801 & 0,442 & 1,019 & 2,428 & 0,069 & 0,353 & 0,070 \\
F10 & 1,560 & 0,956 & 0,203 & 0,754 & 0,324 & 0,393 & 0,082 & 0,033 & 0,027 \\
F11 & 1,327 & 1,179 & 0,680 & 0,664 & 1,187 & 2,790 & 0,062 & 0,229 & 0,073 \\
\hline
\end{tabular}

Tablo 12: Toplam Baskınlık Matrisi

\begin{tabular}{llllllllllll}
\hline Alternatif & F1 & F2 & F3 & F4 & F5 & F6 & F7 & F8 & F9 & F10 & F11 \\
\hline F1 & 0 & 0 & 0 & 0 & 0 & 0 & 0 & 0 & 0 & 0 & 0 \\
F2 & 0 & 0 & 0 & 0 & 1 & 0 & 0 & 0 & 0 & 0 & 0 \\
F3 & 1 & 0 & 0 & 0 & 0 & 0 & 0 & 0 & 0 & 0 & 0 \\
F4 & 0 & 0 & 0 & 0 & 1 & 0 & 0 & 0 & 0 & 0 & 0 \\
F5 & 0 & 0 & 0 & 0 & 0 & 0 & 0 & 0 & 0 & 0 & 0 \\
F6 & 0 & 0 & 0 & 0 & 1 & 0 & 0 & 0 & 0 & 0 & 0 \\
F7 & 0 & 0 & 0 & 0 & 1 & 0 & 0 & 0 & 0 & 0 & 0 \\
F8 & 0 & 0 & 0 & 0 & 0 & 0 & 0 & 0 & 0 & 0 & 0 \\
F9 & 0 & 0 & 0 & 0 & 1 & 0 & 0 & 0 & 0 & 0 & 0 \\
F10 & 1 & 1 & 0 & 1 & 1 & 1 & 1 & 1 & 0 & 0 & 0 \\
F11 & 0 & 0 & 0 & 0 & 1 & 0 & 0 & 0 & 0 & 0 & 0 \\
\hline
\end{tabular}

Toplam baskınlık (E) matrisine göre alternatiflerin (karar noktalarının) birbirlerine göre üstünlükleri dikkate alınarak nihai sıralama yapılmıştır. ELECTRE yönteminin 2013 yılına ilişkin nihai sonuç sıralaması Tablo 13'de gösterilmiştir. 
Yalova Sosyal Bilimler Dergisi

Tablo 13: 2013 yılına göre ELECTRE sıralaması

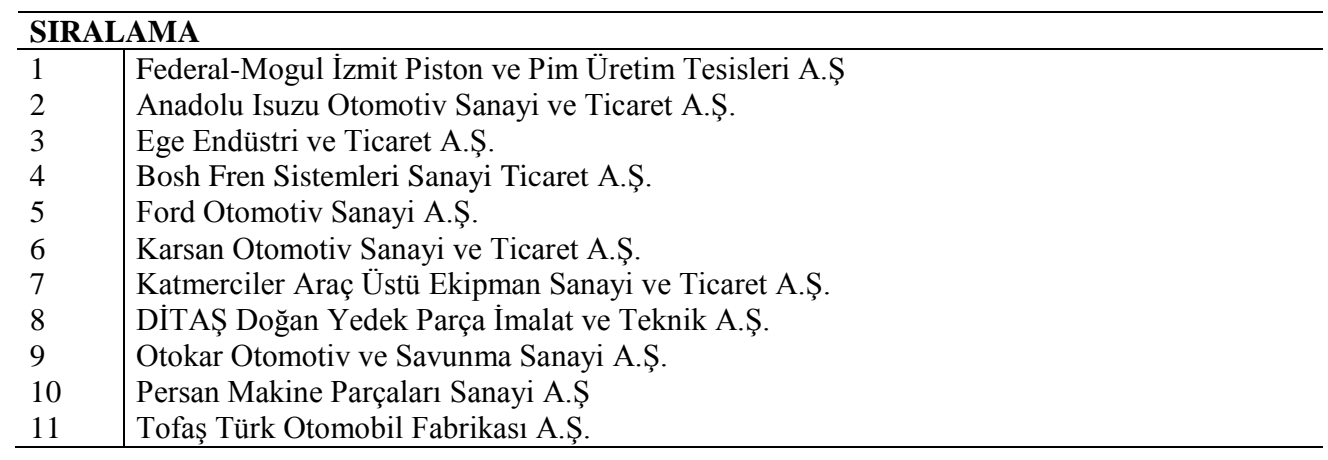

Bu şekilde diğer yıllarda analize tabi tutulmuş ve 2011-2015 yılları arası firmaların ELECTRE sıralaması elde edilmiştir. Sonuçlar yıllara göre Tablo 14'de gösterilmiştir.

Tablo 14:Yıllara göre alternatiflerin ELECTRE sıralaması

\begin{tabular}{llllll}
\hline S1ralama/Y11 & 2011 & 2012 & 2013 & 2014 & 2015 \\
\hline 1 & F5 & F5 & F5 & F5 & F5 \\
2 & F2 & F7 & F1 & F4 & F3 \\
3 & F3 & F8 & F4 & F3 & F2 \\
4 & F6 & F10 & F2 & F11 & F4 \\
5 & F4 & F1 & F6 & F8 & F9 \\
6 & F1 & F2 & F7 & F2 & F3 \\
7 & F11 & F6 & F8 & F9 & F1 \\
8 & F7 & F4 & F3 & F6 & F6 \\
9 & F10 & F9 & F9 & F7 & F7 \\
10 & F9 & F3 & F10 & F10 & F11 \\
11 & F8 & F11 & F11 & F1 & F8 \\
\hline
\end{tabular}

ELECTRE yönteminin sonuçları değerlendirildiğine yine tüm yıllarda diğer yöntemlerde de olduğu gibi F5 firması en iyi performans değerine sahip olmuştur. Diğer sıralamalarda farklılık yöntemlerin adımlarının ve kullanılan metodolojinin farklılı̆̆ından kaynaklanmaktadır. Fakat bu farklılıkların önemli sayılabilecek düzeyde olmadığ1 görülmektedir. Yöntemde 2011 ve 2015 yıllarında F8, diğer y1llarda ise F11 firmasının en kötü performans değerine sahip olduğu belirlenmiştir.

\section{Sonuç ve Değerlendirme}

Yatırımcılar işletmelere yatırım yapmadan önce o işletmelerin yatırım yapmaya değer olup olmadığını, kendilerine kazanç sağlayıp sağlayamayacağı hakkında düşünce sahibi olmak ister. Bu hedefle söz konusu işletmelerin mali tablolarından finansal oranlarına bakarlar. Ancak bu oranların her biri farklı bir durumu ifade eder. Bu verilerden biri olumlu bir düşünceye kanaat getirirken bir diğeri olumsuz yönde düşünmeyi gerektirebilir. Dolayısıyla bu çelişkiden kurtulma ihtiyacı her zaman araştırma konusu olmuştur. $\mathrm{Bu}$ amaçla birçok finansal veriyi tek bir skor hâline indirgemek için birden fazla yöntem verilere uygulanmıştır. 
Bu çalışmada da TOPSIS, AHP, VIKOR ve ELECTRE yönteminin otomotiv imalat sektöründeki işletmelerde finansal performans göstergesi olarak kullanılabileceğini teyit amaçla üç ayrı uygulama yapılmış ve işletmelerin mali tablolarından edinilen finansal oranlarına göre 2011-2015 yılları kapsamında performans skorları belirlenmiştir. Çalışmada AHP yönteminde ağırlıklandırılmak üzere ele alınan kriterlere göre işletmeler arasında sıralama oluşturulmuştur. Yüzdelik olarak ifade edildiğinde aralarında çok büyük farklılık olmayan kriterlerden en önemlisi dönem net kâr//öz kaynak kriteri olmuştur. İşletmelerin sahip oldukları bu değere göre hesaplamalarda ve aynı zamanda elde edilen satışlara ilişkin kâr oranını bularak işletmenin başarılarına göre sıralama yapılmıştır. Yapılan bu kriter ağırlıklarında finansal başarılarına göre sıralanan işletmeler bulunmuştur.

İlk uygulamada işletmelerin performansları TOPSIS yöntemine göre değerlendirilmiştir. İkinci uygulamada VIKOR yöntemi kullanılmıştır. Üçüncü uygulamada ise ELECTRE yöntemi kullanılmıştır. Üç ayrı uygulamanın sonuçlarına bakıldığında sırasıyla F5, F4 ve F2 firmalarının üst sıralarda olduğu görülmüş̧ür. Ancak diğerlerine göre yatırımcısına en çok getiri sağlayacak firmanın Federal-Mogul İzmit Piston ve Pim Üretim Tesisleri A.Ş. (F5) olduğu rahatça söylenebilir.

Bütün uygulamaların sonuçlarının birbirine oldukça benzer çıktığı görülmektedir. Dolayısıyla uygulamanın tutarlı olduğu kanaatine varılmasında hiçbir sakınca yoktur.Bu çalışma baz alınarak ilerleyen çalışmalarda kullanılan çok ölçütlü karar verme yöntemleri temel alınarak matematiksel model kurulabilir ve temel alınan işletmeler için performans kriterlerinden bazıları hedefe dönüştürülebilir.

\section{Kaynakça}

Acar, M. (2003) “Tarımsal İşletmelerde Finansal Performans Analizi.”, Erciyes Üniversitesi İktisadi ve İdari Bilimler Fakültesi Dergisi, 20, 21-37.

Akal, Z. (1996)Işsletmelerde Performans Ölçüm ve Denetimi: Çok Yönlü Performans Göstergeleri, Milli Prodüktivite Merkezi Yayınları.

Akyüz, Y., Bozdoğan, T. \&Hantekin, E., (2011) "TOPSIS Yöntemiyle Finansal Performansın Değerlendirilmesi ve Bir Uygulama”, Afyon Kocatepe Üniv., İ.I.B.F. Dergisi, 3(1), 73-92.

Alağaş H.M., Bedir N., Mermi Ö.S., Kızıltaş Ş. \& Eren T. (2016) Ana Haber Bültenlerinin AHPTOPSIS ile Değerlendirilmesi.,2. Uluslararası Medya Çalışmaları Kongresi, Antalya, Türkiye, 20-23 Nisan.

Albayrak, Y. E. \& Erkut, H. (2010) "Banka Performans Değerlendirmede Analitik Hiyerarşi Süreç Yaklaşımı.", İstanbul Teknik Üniversitesi Dergisi,4(6),47-58.

Alp, S.\& Engin, T. (2011) “Trafik Kazalarının Nedenleri Ve Sonuçları Arasındaki İlişkinin TOPSIS ve AHP Yöntemleri Kullanılarak Analizi ve Değerlendirilmesi."İstanbul Ticaret Üniversitesi, Fen Bilimleri Dergisi, 10(19), 65-87.

Alptekin, N. \&Şıklar, E. (2009) "Türk Hisse Senedi Emeklilik Yatırım Fonlarının Çok Kriterli Performans Değerlendirmesi: TOPSIS Metodu.”, Dumlupınar Üniversitesi Sosyal Bilimler Dergisi,25, 185-196. 
Yalova Sosyal Bilimler Dergisi

Atmaca, M. (2012)“iMKB'de İşlem Gören Spor Şirketlerinin TOPSIS Yönetimi ile Finansal Performans Değerlendirmesi.", İktisat Iş̧letme ve Finans, 27(320), 91-108.

Ayan, E., Cihan, Ş., Eren, T., Topal, T., \&Yıldırım, E.K. (2016) “AHP ve TOPSIS Yöntemleri ile Ekokardiografi Cihazı Seçimi.”,Sağlık Bilimleri ve Meslekleri Dergisi, 4(1), 41-49.

Baykal, İ.Ö., (2007) Çok Ölçütlü Karar Verme Yöntemlerinin Personel Seçimi Problemine Uygulanması, Galatasaray Üniversitesi, Fen Bilimleri Enstitüsü, Yayınlanmamış Yüksek Lisans Tezi.

Bedir N. \&Eren T. (2015) “AHP-PROMETHEE Yöntemleri Entegrasyonu ile Personel Seçim Problemi: Perakende Sektöründe Bir Uygulama.”, SocialSciencesResearchJournal, 4 (4), 4658, 2015.

Bedir, N.,Alağaş, H.M. \&Eren, T. (2017) “Çok Ölçütlü Karar Verme ile Demontaj Hattı Dengeleme.”, International Journal of EngineeringResearchand Development, 9(1) 11-18.

Benligiray, S. (1999). İnsan Kaynakları Açısından Otellerde Performans Yönetimi, Anadolu Üniversitesi, 6-7.

Biçer, T. (1997). Güçlü İnsan Güçlü Şirket, Human Resources, 1, 7, İstanbul.

Brans, J.P. \&Vincke, P., (1985). “A PreferenceRankingOrganizationMethod: The PROMETHEE Methodfor MCDM.”, Management Science, 31(6), 647-656.

Bulgurcu, B.K., (2012)“Application of TOPSIS Techniquefor Financial Performance Evaluation of TechnologyFirms in IstanbulStock Exchange Market.”, SocialandBehavioralSciences 62, 1033-1040.

Büyük Larousse Sözlük ve Ansiklopedisi, Interpress Basın ve Yaylncılık, İstanbul, 1992.

Chu, M.T.,Shyu, J., Tzeng, G.H. \&Khosla, R. (2007) “ComparisonAmong Three AnalyticalMethodsfor Knowledge CommunitiesGroupDecision Analysis.”,ExpertSystemswith Applications, 33(4), 1011-1024.

Çalışkan, E. \& Eren, T., (2016) "Bankaların Performanslarının Çok Kriterli Karar Verme Yöntemiyle Değerlendirilmesi.”,Ordu Üniversitesi Bilim ve Teknoloji Dergisi, 6 (2), 85-107.

Demirci, M., Şahinkul, V. \&Eren, T. (2017) “Oyun Teorisi Yaklaşımı İle Portföy Yönetimi Optimizasyonu Hisse Yatırım Uygulaması.”, Bankacılık ve Finansal Araştırmalar Dergisi, 4(1), 21-37.

Demirel, N. Ç. \&Yücenur, G. N. (2011) "TheCruise Port PlaceSelection Problem WithExtendedVIKOR AndANP MethodologiesUnderFuzzyEnvironment.",In Proceedings of the World Congress on Engineering , 2, 6-8.

Demireli, E. (2010). “TOPSIS Çok Kriterli Karar Verme Sistemi: Türkiye’deki Kamu Bankaları Üzerine Bir Uygulama.”,Dokuz Eylül Üniversitesi, Girişimcilik ve Kalkınma Dergisi, 5(1), 39-51.

Dumanoğlu, S., (2010) “İMKB'de İşlem Gören Çimento Şirketlerinin Mali PerformansınınTOPSIS Yöntemi İle Değerlendirilmesi.”, Marmara Üniversitesi İI.̇.B.F. Dergisi, 29(2), 323-339.

Eleren, A. \&Karagül M. (2008) “1986-2006 Türkiye Ekonomisinin Performans Değerlendirmesi.”, Celal Bayar Üniversitesi İ.I.B.F. Yönetim ve Ekonomi Dergisi, 15(1),1-14.

Ertuğrul, İ.\& Karakaşoğlu, N., (2008) "Banka Şube Performanslarının VIKOR Yöntemi İle Değerlendirilmesi”, Endüstri Mühendisliği Dergisi, YA/EM 2008 Özel Sayısı, 20(1), 19-28.

Genç, T. (2013) "PROMETHEE Yöntemi Ve GAIA Düzlemi.”, Afyon Kocatepe Üniversitesi İktisadi ve İdari Bilimler Fakültesi Dergisi, 15(1), 121-142.

Geyik, O., Tosun, M., Ünlüsoy, S., Hamurcu, M. \& Eren, T. (2016) “Kitap Basımevi Seçiminde AHP Ve TOPSIS Yöntemlerinin Kullanımı.”,Uluslararası Sosyal ve Ĕ̈itim Bilimleri Dergisi, 3 (6), 106-126. 
Yalova Sosyal Bilimler Dergisi

Grady, M. W. (1991) “PerformanceMeasurement: ImplementingStrategy.”,Strategic Finance, 72(12), 49.

Güneri, A.F. \&Şahin, H., (2007). “AHP ve Fuzzy AHP ile Türkiye’de Uygun Tersane Seçimi.”, Gemi ve Deniz Teknolojisi, 172, 7-21.

Hosseini, S.H.,Ezazi, M.E., Heshmati, M.R. \&Reza, S.M., (2013) “Top CompaniesRankingBased on Financial Ratiowith AHP-TOPSIS CombinedApproachandIndices of TehranStock Exchange.”, International Journal of Economicsand Finance,5(3), 126.

Hwang, C.L.,Young, J.L. \&Ting, Y.L. (1993) “A NewApprochForMultipleObjectiveDecisionMaking.”, Computers\&OperationResearch, 20(8), 889-899.

İnce, Ö., Bedir, N. \& Eren, T. (2016) "Hizmetleri Talebi Etkileyen Faktörlerin AHP Yöntemi ile Ağırlıklarının Belirlenmesi”, 10. Sağglk ve Hastane İdaresi Kongresi,16-18, 1-3 Aralık 2016, Ankara.

Karakaş, B. \& Rengin, A, (2003) "Kamu Kurumlarında Performans Yönetimi Önemli midir?", Kamu Yönetiminde Kalite 3, 337-351.

Liou, J.J.H. \&Chuang, Y.T., (2010) "Developing a Hybrid Multi-Criteria Model forSelection of Outsourcing Providers.”, ExpertSystemswith Applications, 37, 3755-3761.

Lixin, D., Ying, L.\&Zhiguang, Z. (2008) "Selection Of Logistics Service Provider Based On Analytic Network Processand VIKOR Algorithm.”, Networking, Sensingand Control, ICNSC 2008IEEE International Conference Proceedings, 1207- 1210.

Menteş, A. (2010) Açık Deniz Yapıları Bağlama Sistemlerinin Dizaynında Bulanık Çok Kriterli Karar Verme Yöntemlerinin Uygulanması, İstanbul Teknik Üniversitesi Fen Bilimleri Enstitüsü, Doktora Tezi.

Mistepe M.U. (1998) “Orman Ürünleri Sanayiinde Eğitim, Teknoloji Ve Verimlilik İlişkileri.”, Cumhuriyetimizin 75. Yllında Ormancılı̆̆ımız SymposiumBook, 21-23October, Harbiye İstanbul, 135-145.

Opricovic, S.\&Tzeng, G.H., (2007) "Extended VIKOR Method in ComparisonwithOtherOutrankingMethods,",EuropeanJournal of OperationalResearch, 178, 514-529.

Opricovic, S. \&Tzeng, G.H. (2004) "CompromiseSolution ByMCDM Methods: A Comparative Analysis Of VIKOR AndTOPSIS.”,EuropeanJournal of OperationalResearch, 156, 445-455.

Ömürbek, V.\&Kınay, B. (2013)“Havayolu Taşımacılığı Sektöründe TOPSIS Yöntemiyle Finansal Performans Değerlendirmesi.”, Süleyman Demirel Üniversitesi İktisadi ve İdari Bilimler Fakültesi Dergisi, 18(3),343-363.

Özder, E.H., Eren, T. \& Çetin, S. (2015) "SupplierSelectionwith TOPSIS andGoal Programming Methods: A Case Study.",Journal of Trends in the Development of MachineryandassociatedTechnology, 19(1), 109-112.

Özer, A., Öztürk, M.\& Kaya, A., (2010) "İşletmelerde Etkinlik ve Performans Ölçmede VZA, Kümeleme ve TOPSIS Analizlerinin Kullanımı: İMKB İşletmeleri Üzerine Bir Uygulama.”,Atatürk Üniversitesi Sosyal Bilimler Enstitüsü Dergisi 14 (1), 233-260.

Roy, B. (1971) "ProblemsandMethodswithMultipleObjectiveFunctions.", Mathematical Programming, 1, 239-266.

Saaty L.T. (1977) A ScalingMethodforPriorities in HierarchicalStructures. University of Pennsylvana.Wharton School, Philadelphia, 15, 234-281

Saaty, T. L. (1980) TheAnalyticHierarchyProcess: Planning, PrioritySetting., ResourcesAllocation. New York: McGraw, 641-658.

Saldanl, A. \&Sırma, İ. (2014) “TOPSIS Yönteminin Finansal Performans Göstergesi Olarak Kullanılabilirliği.”,Marmara Üniversitesi Öneri Dergisi,2(41), 185-202. 
Yalova Sosyal Bilimler Dergisi

Şahin, M., İş İdaresi, Fasikül 1., Açıkönretim Fakültesi Yayınları, No:11.

Şahin, M., İş İdaresine Giriş, Fasikül 2, Açıköğretim Fakültesi Yayınları, 72.

T.C. Bilim Sanayi Ve Teknoloji Bakanlı̆ı̆ (2013/1). Otomotiv Sektörü Raporu, Ankara

Türkmen, S.Y. \&Çağıl, G., (2012) “IMKB' ye Kote Bilişim Sektörü Şirketlerinin Finansal Performanslarının TOPSIS Yöntemi ile Değerlendirilmesi.”, Maliye Finans Yazıları, 26(95), 59-78.

Tzeng, G.H., Lin, C.W. \&Opricovic, S. (2005) "Multi-Criteria Analysis of AlternativeFuelBusesforPublicTransportation.”,EnergyPolicy, 33, 1373-1383.

Tzeng, G.H.\&Huang, J.J. (2011) MultipleAttributeDecisionMakingMethodsand Applications, United States Of America: CRC Press Taylor \& Francis Group, LLC, 69-71.

Ustasüleyman, T. (2009) "BankacılıkSektöründeHizmet Kalitesinin Değerlendirilmesi: AHP-TOPSIS Yöntemi”, Bankacılık Dergisi, 69(1),33-43.

Uygurtürk, H., \&Korkmaz, T. (2012) "Finansal Performansın TOPSIS Çok Kriterli Karar Verme Yöntemi ile Belirlenmesi: Ana Metal Sanayi İşletmeleri Üzerine Bir Uygulama.”, Eskişehir Osmangazi Üniversitesi İktisadi ve İdari Bilimler Dergisi, 7(2).

Wang, T.C., Lee, H.D. \&Wu, C.C., (2007) A Fuzzy TOPSIS ApproachwithSubjectiveWeightsandObjectiveWeights, Proceedings of the 6th WSEAS International Conference on AppliedComputerScience, 6, April 15-17, 2007, 1-6.

Wua, H.Y., Tzeng, G.H. \&Chen, Y.H. (2009) “A Fuzzy MCDM ApproachForEvaluatingBankingPerformanceBased On BalancedScorecard.”, ExpertSystemswith Applications, 36(6), 10135-10147.

Yalama, A. \&Sayım, M. (2008) "Veri Zarflama Analizi İle İmalat Sektörünün Performans Değerlendirmesi.,"Dokuz Eylül Üniversitesi İktisadi ve İdari Bilimler Fakültesi Dergisi,23(1), 89-107.

Yang,C.\&Wang, T. (2006) "VIKOR Method Analysis of Interactive Trade in Policy-Making.", The Business Review, 6(2), 77-85.

Yayar, R.\& Baykara, H.V., (2012) "TOPSIS Yöntemi ile Katılım Bankalarının Etkinliği ve Verimliliği Üzerine Bir Uygulama.”, Business andEconomicsResearchJournal. 3(4), 21-42.

Yoon, K.P. \&Hwang, C.L. (1981)MultipleAttirubeDecisionMaking An Introduction, SageUnivesityPaper Series Quantitative Applications in theSocialSciences, No:07-14.

Yu, P.L. (1973) “A Class Of Solutions ForGroupDecisionProblems.”,Management Science, 19(8), 936-946

Yurdakul, M. \& İç, Y.T., (2003) “Türk Otomotiv Firmalarının Performans Ölçümü ve Analizine Yönelik TOPSIS Yöntemini Kullanan Bir Örnek Çalışma.”, Gazi Üniversitesi Mühendislik Mimarlık Fakültesi Dergisi, 18(1), 1-18.

Zeleny, M. (1982) MultipleCriteriaDecisionMaking. Newyork: Mc-Graw-Hill.

Zerenler, M., (2003) Kriz Dönemlerinde İşletmelerde Üretim Süreci Esnekliğinin Şirketlerin Performans ve Yaşam Sürelerine Etkileri, Yayınlanmamış Doktora Tezi, Konya.

http://www.borsaistanbul.com/veriler/verileralt/mali-tablolar-arsiv, 1.12.2015

http://www.iso.org.tr/Sites/1/content/500-buyuk-liste.html?j=5024132, 4.12.2015

http://www.kap.gov.tr/, 4.12.2015

http://www.odd.org.tr/folders/2837

http://www.tuik.gov.tr 